\title{
Low-temperature reduction of acyclic carvomentholactone derivatives with diisobutylaluminum hydride in methylene chloride
}

\author{
(C) Marina P. Yakovleva, ${ }^{+}$Valentina A. Vydrina, \\ Rasul R. Sayakhov, and Gumer Yu. Ishmuratov* \\ Ufa institute of Chemistry Ufa Federal Research Centre of the Russian Academy of Sciences \\ Prospekt Oktyabrya, 71. Ufa, 450054. Republic of Bashkortostan, Russia. \\ Phone: +7 (347) 235-58-01. E-mail: insect@anrb.ru
}

*Supervising author; ${ }^{+}$Corresponding author

Keywords: low-temperature reduction, seven-membered lactones, diisobutylaluminium hydride, carvomentholactone, methyl (3R)-6-hydroxy- and (3R)-6-oxo-3-isopropylheptanoates.

\begin{abstract}
Earlier, we discovered a novel reaction in the chemistry of organoaluminum compounds - the formation of O-isobutyl acetals during low-temperature $\left(-70{ }^{\circ} \mathrm{C}\right)$ treatment of a number of seven-membered lactones with a twofold (or more) molar amount of diisobutylaluminium hydride in methylene chloride. In addition, it was shown that the acyclic derivatives of (-)-mentholactone - methyl 6-hydroxy-3,7-dimethyl-octanoate and its 6-oxo analogue - also enter into the low-temperature reduction reaction of diisobutylaluminum hydride in methylene chloride. Moreover, methyl 6-hydroxy-3,7-dimethyloctanoate in this reaction behaves similarly to (-)-mentholactone: when 4 equivalents of diisobutylaluminium hydride acts on it, the reaction proceeds with the predominant formation of isobutyl acetal as the only (2S,7S)-epimer. Methyl 6-oxo-3,7-dimethyl octanoate in a low-temperature reduction reaction with 4 equivalents of diisobutylaluminium hydride in methylene chloride acts as a mixture of (-)-mentholactone and isomentolactone, leading to a mixture of $(2 S, 7 S)-,(2 S, 7 R)$ and $(2 R, 7 R)$-isobutyl acetals in a ratio of 3.2: 1.3: 1.0, respectively. In the present work, when lowtemperature reduction was involved in the reaction with diisobutylaluminium hydride, methyl (3R)-6hydroxy- or (3R)-6-oxo-3-isopropylheptanoates available from carvomentolactone reacted without the formation of isobutyl acetal: a mixture of (2: 1) 6-hydroxy-(3R)-isopropylheptanal and (4R)-isopropyl-7methyloxepan-2-ol was obtained.
\end{abstract}

\section{References}

[1] G.Yu. Ishmuratov, M.P. Yakovleva, V.A. Vydrina, E.F. Khasanova, R.R. Muslukhov, N.M. Ishmuratova, G.A. Tolstikov. Study of low-temperature reduction of (-)-mentholactone the directed synthesis of insect pheromones. Chemistry of plant raw materials. 2007. No.3. P.23-32. (russian)

[2] G.Y. Ishmuratov, V.A. Vydrina, M.P. Yakovleva, E.F. Valeeva, R.R. Muslukhov, G.A. Tolstikov. Novel reaction in the chemistry of organoaluminum compounds. Russ. J. Org. Chem. 2011. Vol.47. No.3. P.472-473. https://doi.org/10.1134/S1070428011030304

[3] G.Y. Ishmuratov, V.A. Vydrina, Y.A. Galkina, M.P. Yakovleva, R.R. Muslukhov, G.A. Tolstikov. Versions of new reaction in the chemistry of organoaluminum compounds. Russ. J. Org. Chem. 2014. Vol.50. No.11. P.1704-1707. https://doi.org/10.1134/S1070428014110311

[4] G.Yu. Ishmuratov, V.A. Vydrina, Yu.A. Galkina, M.P. Yakovleva, A.A. Kravchenko, R.R. Muslukhov, A.G. Tolstikov. Low-temperature reduction by diisobutylaluminum hydride in $\mathrm{CH}_{2} \mathrm{Cl}_{2}$ of sevenmembered lactones from betulin and $S$-(+)-camphor. Chem. Nat. Compd. 2015. Vol.51. No.4. P.716720. https://doi.org/10.1007/s10600-015-1391-8

[5] G.Yu. Ishmuratov, V.A. Vydrina, Yu.A. Galkina, M.P. Yakovleva, R.R. Muslukhov, L.V. Kravchenko, D.Sh. Sabirov, A.G. Tolstikov. Reduction at low temperature of isomentholactone with diisobutylaluminum hydride in $\mathrm{CH}_{2} \mathrm{Cl}_{2}$. Russ. J. Org. Chem. 2015. Vol.51. No.8. P.1180-1182. https://doi.org/10.1134/S1070428015080205

[6] G.Y. Ishmuratov, V.A. Vydrina, M.P. Yakovleva, Yu.A. Galkina, R.R. Muslukhov, G.A. Tolstikov. Low-temperature hydride reduction of (3R)-carvomentholactone. Chem. Nat. Compd. 2012. Vol.47. No.6. P.896-898. https://doi.org/10.1007/s10600-012-0098-3

[7] G.Y. Ishmuratov, V.A. Vydrina, Y.A. Galkina, M.P. Yakovleva, A.A. Kravchenko, R.R. Muslukhov, A.G. Tolstikov. Low-temperature reduction of acyclic (-)-mentholactone derivatives with 
LOW-TEMPERATURE REDUCTION OF ACYCLIC CARVOMENTHOLACTONE DERIVATIVES WITH ...

diisobutylaluminum hydride in methylene chloride. Russ. J. Org. Chem. 2015. Vol.51. No.7. P.947-950. https://doi.org/10.1134/S1070428015070106

[8] A. Gordon, R. Ford. Sputnik khimika. Moscow: Mir. 1976. 541p. (russian)

[9] R.A. Fernandes, A.B. Ingle. Synthetic studies on C14 cemdranoids: synthesis of C1-12 fragment of sarcophytonolides E-G and L and C5-11 fragment of sarcophytonolide L. Tetrahedron Lett. 2011. Vol.52. P.458-460. 